prof. dr hab. Jan Przybyłek ${ }^{1}$

\title{
STAN I MOŻLIWOŚCI ODBUDOWY STOSUNKÓW WODNYCH NA POJEZIERZU GNIEŹNIEŃSKIM PO ZAKOŃCZENIU ODKRYWKOWEJ EKSPLOATACJI WEGLA BRUNATNEGO
}

https://doi.org/10.18778/8220-655-5.02

\begin{abstract}
Streszczenie: Wielkopolska cechuje się największymi deficytami wody w kraju. Od lat region ten nawiedzają zjawiska suszy z problemami wysychania małych cieków wodnych i obniżania się zwierciadeł wody w jeziorach. W szczególności dotyczy to Pojezierza Gnieźnieńskiego, gdzie do czynników klimatycznych doszły jeszcze wieloletnie procesy odwadniania kolejnych odkrywek PAK KWB Konin z zasięgiem kopalnianego leja depresji sięgającego aż na tereny Powidzkiego Parku Krajobrazowego z jeziorami w głębokich rynnach glacjalnych, co sprzyja katastrofalnemu obniżaniu się w nich lustra wody pod wpływem górniczych systemów odwodnieniowych. Ujemny klimatyczny bilans wodny oraz lej depresji obniżający dynamiczne zwierciadło wody w wodonośnych poziomach użytkowych są również powodem zmniejszania się zasobów dyspozycyjnych dla ujęć wód podziemnych w gminach Pojezierza Gnieźnieńskiego. W artykule przedstawiono aktualny stan stosunków wodnych na tym obszarze oraz koncepcję ratowania jezior poprzez przyspieszone zalewanie końcowych wyrobisk górniczych, powierzchniowymi wodami zewnętrznymi doprowadzanymi z Kanału Ślesińskiego zasilanego zasobami wodnymi z rzeki Warty.
\end{abstract}

Słowa kluczowe: odwadnianie górnicze, zalewanie wyrobisk, rekultywacja wodna, odnawialność wód podziemnych, bilans wodny.

\section{Wprowadzenie}

Eksploatacja górnicza węgla brunatnego w KWB Konin, połączona z wielkopromiennym odwadnianiem odkrywek we wschodniej części Pojezierza Gnieźnieńskiego pomiędzy goplańską rynną subglacjalną (Kanał Ślesiński) a rynną subglacjalną Powidz-Ostrowo w Powidzkim Parku Krajobrazowym (PPK), rozpoczęła się w 1958 roku od odkrywki Pątnów, założonej na złożu węglowym w sąsiedztwie Jeziora Mikorzyńskiego w biegu Kanału Ślesińskiego (ryc. 1). W wyniku budowy i odwadniania kolejnych odkrywek: Kazimierz Południe, Kazimierz Północ, Jóźwin I, Jóźwin IIA, Jóźwin IIB rozległy lej depresji odwodnienia górniczego rozbudował się w wielowarstwowym systemie wodonośnym w kierunku NE, sięgając jezior PPK. Wraz $\mathrm{z}$ upływem czasu, w drugiej dekadzie XXI wieku, lej depresji objął swoim zasięgiem struktury hydrogeologiczne w piętrze czwartorzędowym i piętrze neogeńskim, związane z jeziorami: Powidzkim, Budzisławskim, Wilczyńskim, Suszewskim i Kownackim, doprowadzając do obniżenia w nich lustra wody i znacznej degradacji przyrodniczej poprzez ograniczenie ich zasilania podziemnego i z czasem infiltrację wód jeziornych do systemu odwodnienia górniczego.

W warunkach wgłębnego odwadniania odkrywek rzędna zwierciadła wody podziemnej w mioceńskich piaskach podwęglowych ukształtowała się w przedziale rzędnych od $37 \mathrm{w}$ odkrywce Pątnów, do 46 m n.p.m. w odkrywce Kazimierz Północ, powodując depresję zwierciadła wody w tym poziomie w wielkości odpowiednio od $47 \mathrm{~m}$ do $38 \mathrm{~m} \mathrm{w}$ stosunku do stanu Kanału Ślesińskiego ze stałą rzędną lustra wody ok. 84 m n.p.m.

${ }^{1}$ Uniwersytet im. Adama Mickiewicza w Poznaniu, Wydział Nauk Geograficznych i Geologicznych, Instytut Geologii, ul. Bogumiła Krygowskiego 10, 61-680 Poznań, janex @amu.edu.pl, ORCID 0000-0002-7692-8273 
Stan i możliwości odbudowy stosunków wodnych na Pojezierzu Gnieźnieńskim po zakończeniu...

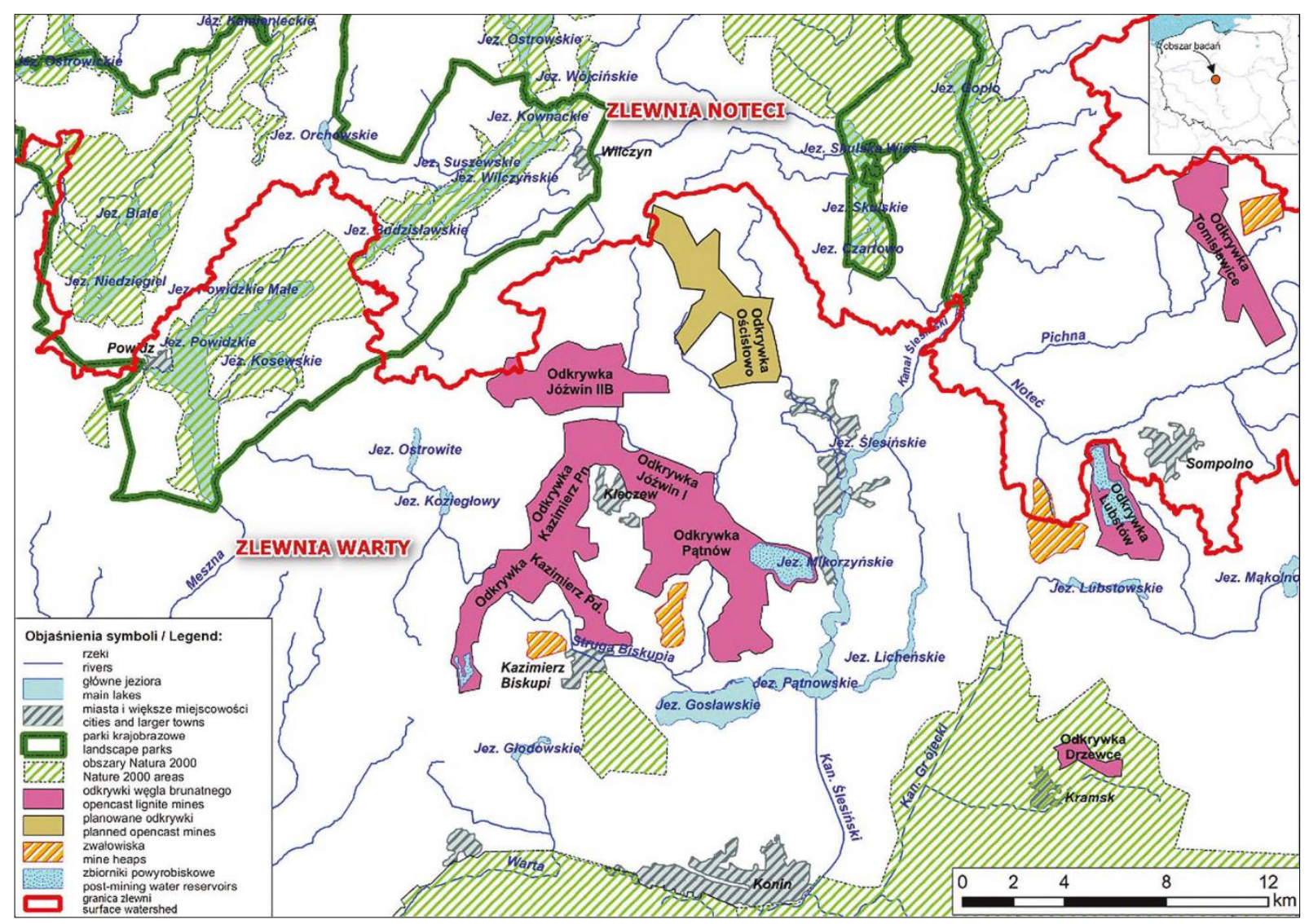

Ryc. 1. Hydrografia i wzajemne położenie jezior i odkrywek KWB Konin na Pojezierzu Gnieźnieńskim Źródło: Przybyłek 2020

Blechacz i Karpa (1969) wykazali, że zwierciadło wody poziomu mioceńskiego kształtowało się pierwotnie przy Jeziorze Budzisławskim i Jeziorze Wilczyńskim na terenie WDK na rzędnej ok. 99 m n.p.m. i obniżało się proporcjonalnie ku bazie jego drenażu naturalnego do 84 m n.p.m. przy Kanale Ślesińskim na odległości ok. 20 km, dzielących obie rynny jeziorne (ryc. 1). Z upływem czasu, w wyniku wzajemnego oddziaływania kolejno zakładanych systemów odwodnieniowych odkrywek Pątnów, Kazimierz Południe, Jóźwin, Kazimierz Północ i Jóźwin IIB, ukształtował się na obszarze Pojezierza Gnieźnieńskiego na północny-zachód od Konina rozległy lej depresji sięgający w kierunku na zachód i północ na odległość ponad $10 \mathrm{~km}$, obejmując łączące się ze sobą regionalne poziomy wodonośne: mioceński i górnokredowy oraz nadległe warstwy wodonośne w utworach czwartorzędowych.

Regionalny lej depresji, rozwijając się intensywnie w stronę jezior w rynnie Powidz-Ostrowo, zagroził wraz z upływem dziesięcioleci zakłóceniem naturalnego bilansu wodnego tych jezior ze skutkiem kilkumetrowego obniżenia się w nich lustra wody, czego przykładem jest wykres stanów Jeziora Wilczyńskiego z obserwacjami z lat 1991-2020 (ryc. 2). 
Jezioro Wilczyńskie
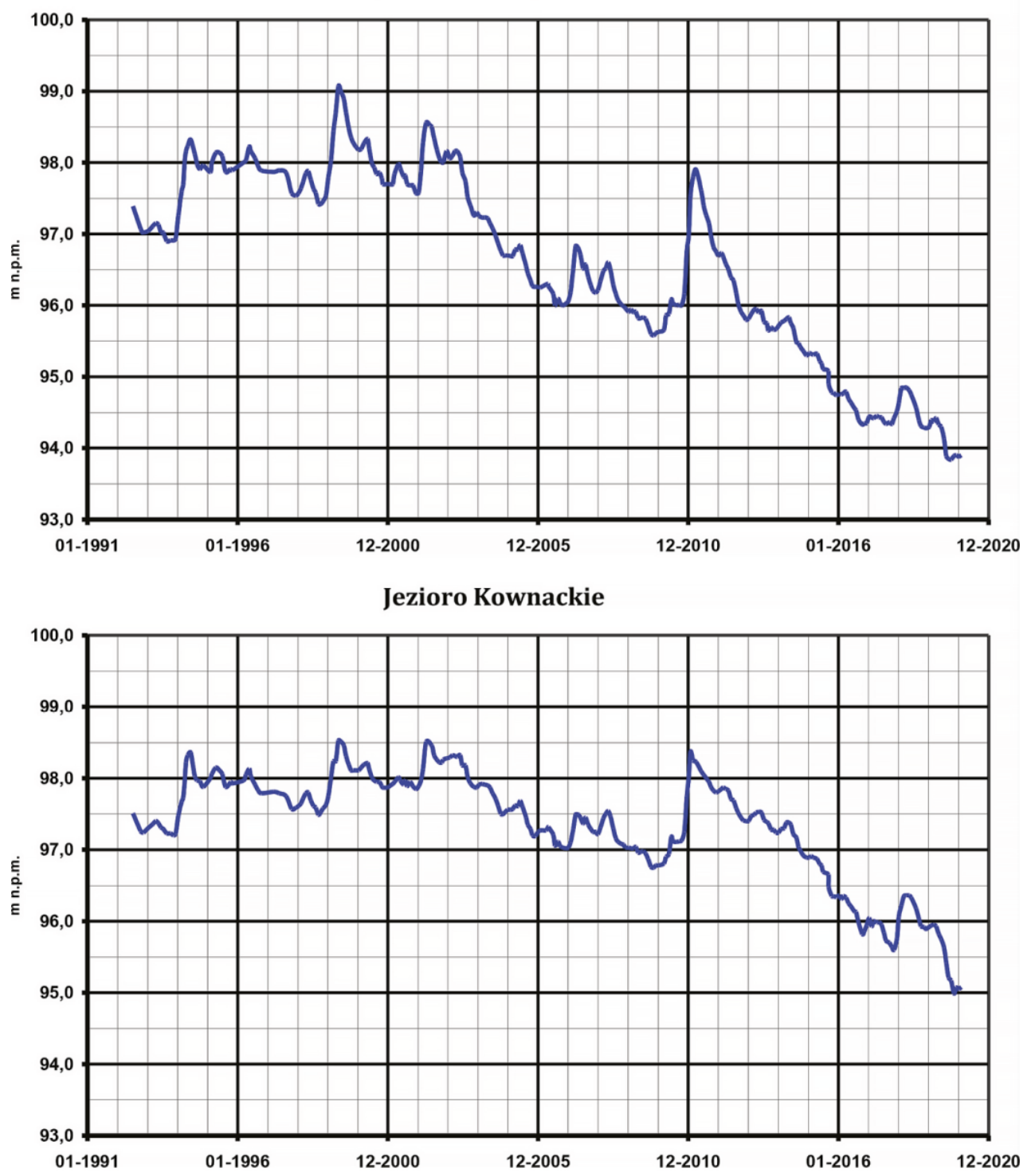

Ryc. 2. Wykresy stanów zwierciadła wody w Jeziorze Wilczyńskim i w Jeziorze Kownackim na terenie Powidzkiego Parku Krajobrazowego w latach 1991-2020, wskazujące na drastyczny ubytek wody w tych jeziorach w ostatnim dziesięcioleciu

Źródło: Przybyłek i in. 2020

W obszarze działalności górniczej, całkowitej przebudowie uległa pierwotna sieć hydrograficzna związana z rejonem wododziału pomiędzy zlewnią Noteci a zlewnią Warty (ryc. 1), utrudnione zostały warunki eksploatacji ujęć wód podziemnych indywidualnych i zbiorowego zaopatrzenia w gminach Kleczew, Kazimierz Biskupi, Ślesin, Wilczyn w powiecie konińskim. W wyniku rozwoju kopalnianego leja depresji przy ujemnym klimatycznym bilansie wodnym w strefie wododziałowej, omawiane jeziora PPK stały się z czasem bezodpływowe, a obszar hydrograficzny o powierzchni ponad $250 \mathrm{~km}^{2}$ w części zlewni Noteci, definiowany jako 
Stan i możliwości odbudowy stosunków wodnych na Pojezierzu Gnieźnieńskim po zakończeniu...

zlewnia kanału Ostrowo-Gopło lub jako zlewnia Jeziora Kownackiego (Marszelewski i in. 2012), już od ponad 20. lat cechuje się brakiem odpływu rzecznego (Przybyłek i Nowak 2011; Nowak 2018, 2020). Złożoność stanu hydrograficznego, bilansu wodnego i roli gospodarki wodno-ściekowej w kształtowaniu się tego bilansu na obszarze Pojezierza Gnieźnieńskiego objętego wpływem odwodnień górniczych przedstawił Nowak (2018) w swojej rozprawie doktorskiej. Problematyka opisywanych zjawisk i ich uciążliwość dla środowiska przyrodniczego i ludzi już od lat 90. XX wieku rodziła pytania o środki zaradcze (Ilnicki 1996). Poczęto rozważać sprawę przerzutu odpowiednio przygotowanych wód wgłębnych ze studziennego odwodnienia górniczego do wysychających jezior, zakładania barier studni chłonnych i nawadniających drenów dla ograniczania nadmiernego rozwoju górniczych lejów depresji.

Po publikacjach naukowych (Ilnicki i Orłowski 2006a, 2006b, 2007; Ilnicki 2008) i licznych publikacjach prasowych podjęto w latach 2006-2008 starania o realizację projektów hydrotechnicznych zasilania Jeziora Budzisławskiego i Jeziora Wilczyńskiego wodami z odwodnienia odkrywki Jóźwin IIB (ryc. 1). W trakcie głośnej batalii społecznej, w tym prasowej oraz urzędowych narad ścierały się w tej sprawie zróżnicowane opinie biologów, wskazujących na unikatowe ekosystemy bardzo wrażliwych łąk ramienicowych (siedlisko przyrodnicze 3140, Natura 2000, Gąbka i Burchardt 2006), hydrologów, hydrogeologów, chemików oraz organizacji proekologicznych, dotyczących głównie technologii zasilania jezior (Przybyłek 2018).

W efekcie, na ochronę unikatowych siedlisk przyrodniczych tych bardzo głębokich jezior wododziałowych o wyjątkowej przezroczystości wody, plany bezpośredniego ich zasilania wodami z odwodnienia górniczego nie zostały w następnych latach zrealizowane. Skutek jest taki, że obecnie pogłębia się degradacja jezior w PPK, a proces ten będzie w kolejnych latach wzrastał, potęgowany niekorzystnym klimatycznym bilansem wodnym Pojezierza Gnieźnieńskiego (Kędziora 2008, 2011; Nowak 2018, 2020; Nowak i Przybyłek 2020) oraz powtarzającymi się bardzo często suszami w Wielkopolsce (Kępińska-Kasprzak 2015). Możliwość zaradzenia tej sytuacji upatruje się aktualnie w przyspieszeniu procesu rekultywacji wodnej końcowego wyrobiska odkrywki Jóźwin IIB, której eksploatację przewiduje się zakończyć w najbliższych latach. Według ostatnich planów PAK KWB Konin, po zakończeniu eksploatacji węgla brunatnego z odkrywki Jóźwin IIB, nie przewiduje się otwarcia kolejnej planowanej odkrywki Ościsłowo (ryc. 1).

Opisana sytuacja otwarła możliwości rozważenia przyspieszonej rekultywacji wodnej wyrobiska górniczego po odkrywce Jóźwin IIB, kształtując w nim akwen wodny zasilany nie tylko z wód podziemnych, z poziomów wodonośnych objętych likwidowanym lejem depresji, co dla wypełnienia zbiornika trwałoby kilkadziesiąt lat, ale również z wykorzystaniem możliwości jego zewnętrznego zasilania z zasobów wód powierzchniowych rzeki Warty w postaci rurociągowego przerzutu wody z Kanału Ślesińskiego, o czym będzie mowa w dalszej części niniejszego artykułu. Przyspieszenie procesu rekultywacji pozwoli na przywrócenie stosunków wodnych sprzyjających odbudowie zasilania jezior Powidzkiego Parku Krajobrazowego poprzez odzyskanie przynależnym im zlewni powierzchniowych i podziemnych, włączonych dotychczas w strefę leja depresji odwodnienia górniczego. 
Jan Przybyłek

\section{Aktualny stan stosunków wodnych w rejonie jezior w strefie leja depresji odwodnienia górniczego}

Bliskie sąsiedztwo aktualnie odwadnianej odkrywki węgla brunatnego Jóźwin IIB powoduje utrzymywanie się stałej, bardzo silnej presji hydrodynamicznej na jeziora: Budzisławskie, Wilczyńskie, Suszewskie i Kownackie, o czym świadczy rozkład hydroizohips stanów wody podziemnej w poziomie trzeciorzędowym (neogeńskim) przedstawiony w postaci mapy hydroizohips na ryc. 3 .
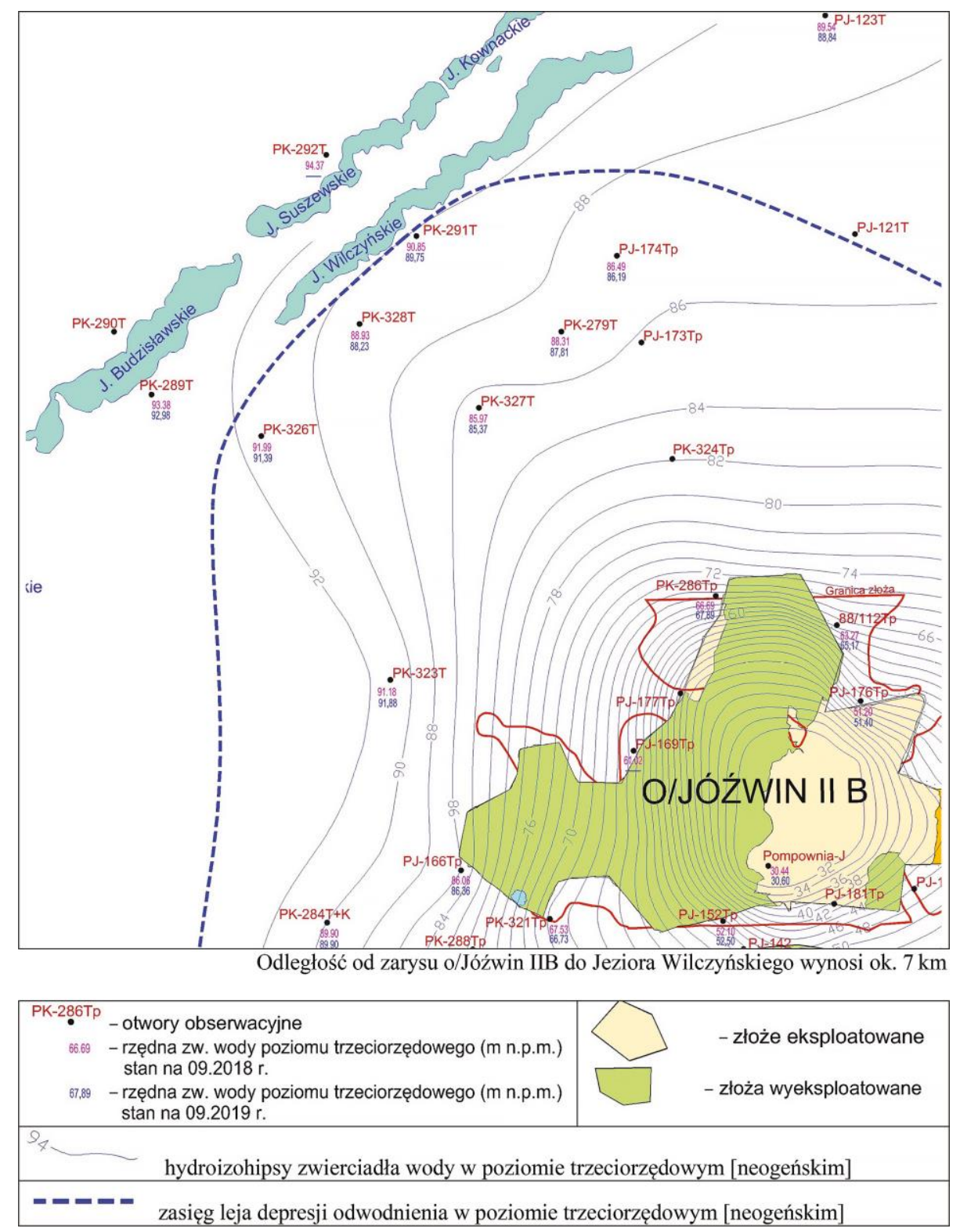

Ryc. 3. Sieć otworów obserwacyjnych (piezometrów) w rejonie jezior Powidzkiego Parku Krajobrazowego (Budzisławskie, Suszewskie, Wilczyńskie) oraz w otoczeniu O/Jóźwin IIB z postacią leja depresji w 2019 r.

Źródło kartograficzne: fragment mapy na rys. 5 opracowania PROXIMA S.A.

(Tarnowski i in. 2020) w wersji z publikacji Przybyłek i in. 2020 
Stan i możliwości odbudowy stosunków wodnych na Pojezierzu Gnieźnieńskim po zakończeniu...

Odwadnianie odkrywki Jóźwin IIB, położonej zaledwie w odległości 7. km od brzegów jezior, odbywa się przy bardzo wysokim stopniu jej zawodnienia, bo utrzymującym się w przewadze poboru wody w ilości ok. $70-80 \mathrm{~m}^{3} / \mathrm{min} \mathrm{z}$ rzędną odprowadzania wód spągowych na poziomie $+30,60$ m n.p.m. W dokumentach ,kopalnianych” podkreśla się, że duże dopływy do odkrywki Jóźwin IIB są wynikiem intensywnego dopływu wód podziemnych (zasilania) od strony północnej z obszaru GZWP nr 144 określanego jako „Wielkopolska Dolina Kopalna” (Dąbrowski 1990) oraz przejmowania wód z doliny Strugi Kleczewskiej, a także licznych dolin erozyjnych, często pod glinami zwałowymi, wypełnionych osadami piaszczysto-żwirowymi. Ilustracją powiązań hydraulicznych pomiędzy jeziorami PPK z odwadnianą odkrywką Jóźwin IIB poprzez układ warstw wodonośnych w strefie odwadniania górniczego jest przekrój hydrogeologiczny Jeziora Suszewskiego i Jeziora Wilczyńskiego (ryc. 4).
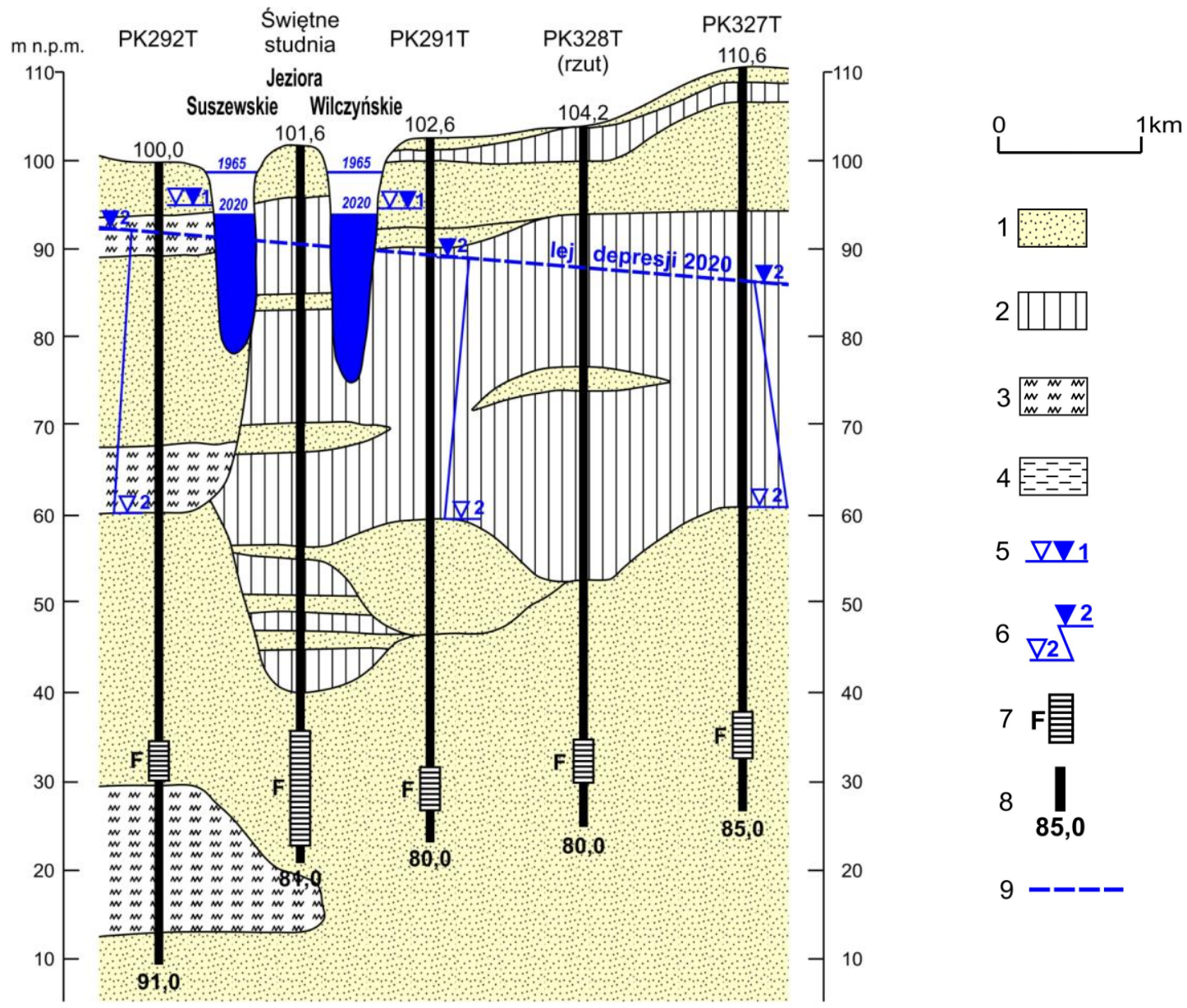

$5 \nabla \nabla 1$
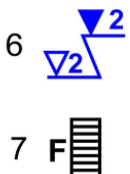

$8 \prod_{85,0}$

9 -ーーー

Ryc. 4. Przekrój hydrogeologiczny Jeziora Suszewskiego i Jeziora Wilczyńskiego obrazujący zakres powiązań hydraulicznych tych jezior z odwadnianą odkrywką Jóźwin IIB poprzez układ warstw wodonośnych $\mathrm{w}$ strefie odwadniania górniczego

Objaśnienia: 1 - utwory piaszczysto-żwirowe, 2 - gliny zwałowe, 3 - mułki, 4 - iły, 5 - zwierciadło swobodne, 6 - zwierciadło naporowe, 7 - głębokość zabudowy filtrów, 8 - głębokość otworów,

9 - profil górniczego leja depresji

Źródło: Przybyłek i in. 2020 
Wrysowany na tym przekroju profil leja depresji odkrywki Jóźwin IIB wskazuje, że wpływ odwodnienia górniczego objął jednoznacznie oba te jeziora, powodując wykazane w nich kilkumetrowe obniżenia zwierciadła wody (ryc. 2) oraz przechwytując dopływy do tych jezior $\mathrm{z}$ ich lokalnych zlewni. Spadek hydrauliczny zwierciadła wody wyznaczony profilem leja depresji na ryc. 4 wynosi $\mathrm{I}=0,0018$. Jego wielkość wskazuje na intensywny odpływ wód podziemnych z rejonu jezior do odkrywki Jóźwin IIB. Według badań na modelu numerycznym (Fiszer i in. 2013) wielkość tego odpływu w ostatnich latach szacuje się na $4,6 \mathrm{~m}^{3} / \mathrm{min}$ do $6 \mathrm{~m}^{3} / \mathrm{min}$. Przyjmując za uzasadnioną wielkość $6 \mathrm{~m}^{3} / \mathrm{min}$ otrzymamy straty bilansowe w zasilaniu jezior wynoszące blisko $3,15 \mathrm{mln} \mathrm{m}^{3}$ wody rocznie. W treści przekroju umieszczono sygnalizację zaistniałego obniżenia lustra wody $\mathrm{w}$ analizowanych jeziorach $\mathrm{w}$ stosunku do ich stanów podawanych na mapach topograficznych z lat 60 . XX wieku. Na podkreślenie zasługuje fakt, że obszar zasilania po stronie wschodniej jezior został prawie całkowicie skaptowany na rzecz odpływu podziemnego w stronę odkrywki Jóźwin IIB.

\section{Koncepcja zasilania zbiornika końcowego w wyrobisku odkrywki Jóźwin IIB zasobami wodnymi rzeki Warty $z$ ich poborem ze szczytowego stanowiska Kanału Ślesińskiego}

W dniu 11 lutego 2020 r. odbyło się w Sejmie RP otwarte posiedzenie Parlamentarnego Zespołu ds. Ochrony Pojezierzy Wielkopolskich, pod przewodnictwem pani Poseł na Sejm RP Pauliny Hennig-Kloski, na którym została przedstawiona wstępnie koncepcja ratowania i ochrony jezior położonych w PPK na Pojezierzu Gnieźnieńskim, w sąsiedztwie odkrywek węgla brunatnego KWB Konin. Ustalono, że należy pilnie podjąć działania zmierzające do zasilania zarówno jezior jak i poddanych rekultywacji wodnej wyrobisk po węglu brunatnym, którymi są odkrywka Kazimierz Północ oraz w niedalekiej przyszłości odkrywka Jóźwin IIB. Długoterminowe działania ratunkowe mogłyby być prowadzone na drodze rurociągowego przesyłu wody z ujęcia wód powierzchniowych - w oparciu o pobór wody z Kanału Ślesińskiego. Kanał Ślesiński stanowi ciąg drogi wodnej o długości $32 \mathrm{~km}$, łączący rzekę Wartę z jeziorem Gopło wraz z jeziorami na jego trasie (ryc. 1). Odcinek tego Kanału z łańcuchem naturalnie połączonych jezior: Pątnowskie, Wąsowsko-Mikorzyńskie, Ślesińskie oraz Czarne tworzy tzw. szczytowe stanowisko Kanału Ślesińskiego o łącznej długości 16,29 km, utrzymywane pomiędzy śluzą w Pątnowie (od południa) oraz śluzą w Gawronach (od północy). Pozycję szczytowego stanowiska Kanału Ślesińskiego wraz z jego charakterystyką liczbową przedstawia ryc. 5.

W trakcie posiedzenia Zespołu Parlamentarnego ustalono, że przerzut wód z Kanału Ślesińskiego w kierunku jezior PPK, w połączeniu z przyspieszoną rekultywacją wodną wyrobiska końcowego odkrywki Jóźwin IIB, musi być poprzedzony specjalistycznymi opracowaniami studialnymi, w tym dokonaniem oceny możliwości zasilania tych jezior zasobami wodnymi rzeki Warty poprzez szczytowe stanowisko Kanału Ślesińskiego.

W celu realizacji tego zamierzenia odbyło się w dniu 19 lutego 2020 r. w Urzędzie Marszałkowskim Województwa Wielkopolskiego spotkanie z Panem Marszałkiem Markiem Woźniakiem, na którym pani poseł Paulina Hennig-Kloska przedstawiła rysujące się plany ratowania jezior w PPK, prosząc o pomoc w uruchomieniu wstępnego opracowania specjalistycznego, 
Stan i możliwości odbudowy stosunków wodnych na Pojezierzu Gnieźnieńskim po zakończeniu...

na co Pan Marszałek wyraził zgodę, wskazując przy tym jako koordynatora opracowania - Wielkopolskie Biuro Planowania Przestrzennego w Poznaniu (WBPP).

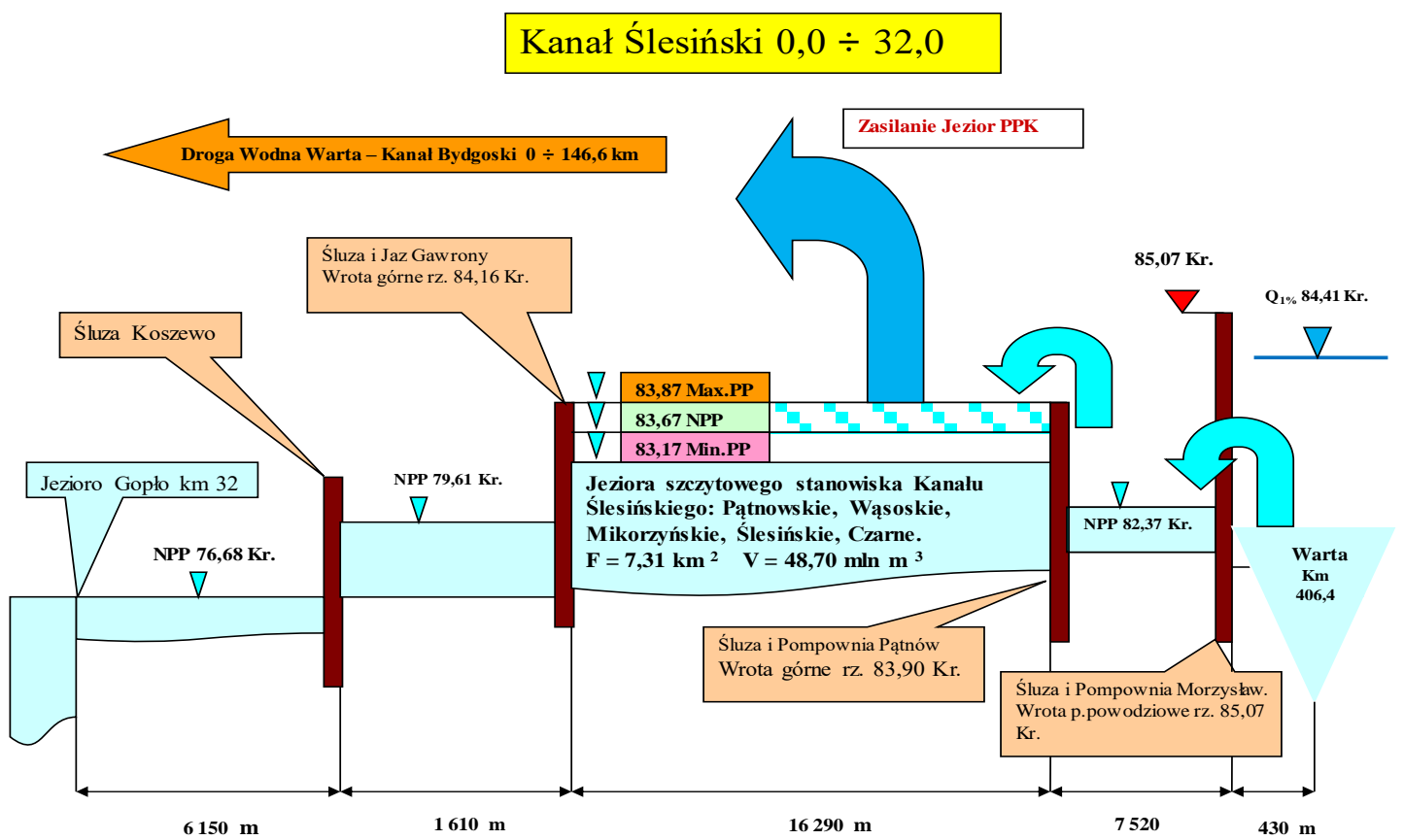

Ryc. 5. Poglądowy schemat szczytowego stanowiska Kanału Ślesińskiego jako miejsca poboru wody powierzchniowej do poprawy zasilania jezior PPK poprzez napełnianie końcowych zbiorników wodnych po odkrywkach PAK KWB Konin - schemat na ryc. 6

Źródło: Przybyłek i in. 2020

Do współpracy z WBPP w Poznaniu został upoważniony profesor dr hab. Jan Przybyłek z Uniwersytetu im. Adama Mickiewicza w Poznaniu. Następnie uchwałą Sejmiku Województwa Wielkopolskiego (18.05.2020 r.) zapewniono środki budżetowe dla WBPP na realizację wstępnego opracowania pn.: „Analiza możliwości zasilania jezior Powidzkiego Parku Krajobrazowego zasobami wodnymi rzeki Warty oraz szczytowego stanowiska Kanału Ślesińskiego". Ekspertyza pod powyższym tytułem została opracowana przez zespół autorski w składzie: prof. dr hab. Jan Przybyłek - hydrogeolog z Instytutu Geologii Uniwersytetu im. Adama Mickiewicza w Poznaniu; prof. UAM, dr hab. Maciej Gąbka - hydrobiolog, Kierownik Zakładu Hydrobiologii na Wydziale Biologii UAM; mgr inż. Witold Kamiński - specjalista hydrotechnik w zakresie urządzeń wodno-melioracyjnych i bilansów wodnych; mgr inż. Roman Wiliński - projektant w zakresie budowli hydrotechnicznych.

Ekspertyzę ukończono w grudniu 2020 r. Opracowanie w formie publikacji zostało przygotowane do druku przez Bogucki Wydawnictwo Naukowe (ISBN 978-83-7986-343-3) i rozpowszechnione w kwietniu 2021 roku przez WBPP w Poznaniu (Przybyłek i in. 2020). Poniżej podane opisy są przedstawione w oparciu o treści tej publikacji. 
Techniczne możliwości przerzutu wody z Warty na szczytowe stanowisko Kanału Ślesińskiego zapewniają następujące urządzenia i obiekty hydrotechniczne:

- $\quad$ kanał sztuczny o długości 430 m od Warty do śluzy komorowej oraz pompowni w Morzysławiu;

- pompownia Morzysław, usytuowana po południowej stronie głowy dolnej przy śluzie Morzysław;

- $\quad$ kanał sztuczny o długości 7520 m od śluzy komorowej w Morzysławiu do śluzy komorowej w Pątnowie (tzw. stanowisko pośrednie kanału);

- pompownia Pątnów, usytuowana po wschodniej stronie głowy dolnej przy śluzie Pątnów;

- łańcuch jezior naturalnie połączonych: Pątnowskie, Wąsosko-Mikorzyńskie, Ślesińskie oraz Czarne, które połączone jest przekopem (sztucznie) o długości 1800 m z Jeziorem Ślesińskim.

Przerzut wody z Warty na szczytowe stanowisko Kanału Ślesińskiego odbywa się dwustopniowo, poprzez przepompowanie wody pompownią Morzysław z kanału o długości $430 \mathrm{~m}$ biegnącego od Warty na stanowisko pośrednie - kanał o długości 7520 m od śluzy komorowej w Morzysławiu do śluzy komorowej w Pątnowie, a następnie z tego kanału przepompowanie wody pompownią Pątnów na stanowisko szczytowe Kanału Ślesińskiego. Schemat poglądowy ilustruje ryc. 5.

Z powodów środowiskowych (szeroko opisanych w Przybyłek i in. 2020), jak również związanych z obecną jakością wody w Warcie oraz Kanale Ślesińskim, bezpośrednie zasilanie jezior PPK wodą z wymienionych źródeł jest niemożliwe. Wobec powyższego dalsze rozważania będą skoncentrowane na zasilaniu pośrednim jezior PPK poprzez sztuczne zalewanie zbiorników końcowych: odkrywki Kazimierz Północ - zbiornik Kleczew oraz odkrywki Jóźwin IIB. Podstawowe dane dotyczące zbiorników końcowych według informacji otrzymanych od PAK KWB Konin S.A. przedstawiono w tab. 1.

Tab. 1. Zestawienie parametrów zbiorników wodnych po eksploatacji odkrywek PAK KWB Konin

\begin{tabular}{|c|c|c|}
\hline Nazwa zbiornika wodnego & $\begin{array}{c}\text { Zbiornik Kleczew po } \\
\text { odkrywce Kazimierz Północ }\end{array}$ & $\begin{array}{l}\text { Zbiornik końcowy po } \\
\text { odkrywce Jóźwin IIB }\end{array}$ \\
\hline Obecny status zbiornika & $\mathrm{W}$ trakcie wypełniania & Planowany do wykonania \\
\hline Aktualna rzędna napełnienia & 75,02 m n.p.m. (30.10.2021) & - \\
\hline Docelowa rzędna napełnienia & 92 m n.p.m. & 93 m n.p.m. \\
\hline Powierzchnia zbiornika & 648 ha & 750 ha \\
\hline Powierzchnia lustra wody przy rzędnej docelowej & 522 ha & 720 ha \\
\hline Pojemność zbiornika przy rzędnej docelowej & ok. $143 \mathrm{mln} \mathrm{m}^{3}$ & ok. $213 \mathrm{mln} \mathrm{m}^{3}$ \\
\hline Minimalna rzędna terenu w zbiorniku & 28,30 m n.p.m. & 24,30 m n.p.m. \\
\hline Głębokość zbiornika & $63,7 \mathrm{~m}$ & $40,3-68,7 \mathrm{~m}$ \\
\hline Przewidywany czas napełniania & 4 lata & 33 lata \\
\hline
\end{tabular}

Objaśnienia: pojemność zbiornika wodnego po odkrywce Jóźwin IIB będzie wyższa od pojemności zbiornika retencyjnego Jeziorsko na rzece Warcie - 202,04 $\mathrm{mln}^{3}$ przy maksymalnym poziomie piętrzenia (Max PP 121,50 m n.p.m.)

Źródło: w oparciu o Przybyłek i in. 2020. 
Stan i możliwości odbudowy stosunków wodnych na Pojezierzu Gnieźnieńskim po zakończeniu...

Podane poniżej informacje o koncepcji zasilania wyrobisk końcowych po odkrywkach PAK KWB Konin przedstawia się w oparciu o treść Ekspertyzy (Przybyłek i in. 2020). Z analizy danych uzyskanych od PAK KBW Konin S.A. przerzut wody z odwodnienia O/Jóźwin IIB do zbiornika Kleczew po odkrywce Kazimierz Północ odbywał się do 2 czerwca 2020 roku $\mathrm{z}$ wydatkiem ok. $0,189 \mathrm{~m}^{3} / \mathrm{s}$ (pomiar w dniu $02.06 .2020 \mathrm{r}$.), natomiast później z wydatkiem ok. $0,802 \mathrm{~m}^{3} / \mathrm{s}$ (pomiar ostatni w dniu 27.10.2020 r.). Przy obecnym tempie zalewania zbiornika Kleczew w ilości ok. $25 \mathrm{mln} \mathrm{m} /$ rok z odwodnienia odkrywki Jóźwin IIB, docelowy poziom zwierciadła wody na rzędnej $92,00 \mathrm{~m}$ n.p.m. może być osiągnięty już po 3-4 latach o ile cały czas byłaby dostarczana woda z odwadniania odkrywki Jóźwin IIB, co może być nierealne w przypadku skrócenia okresu końcowej eksploatacji złoża węglowego. W przypadku zbiornika końcowego odkrywki Jóźwin IIB, przewidywany czas napełniania określono na ok. 33 lata. Czas ten może ulec skróceniu w przypadku zasilenia zbiornika końcowego wodami przerzucanymi systemem rurociągowym DN1000 mm z Kanału Ślesińskiego przy zasilaniu wyrobiska ilością ok. $1 \mathrm{~m}^{3} / \mathrm{s}$ wody powierzchniowej przez połowę roku w okresach suchych i przez okres całego roku w warunkach normalnych i okresach mokrych (średnio ok. 9 miesięcy w roku). Przy takiej podaży wody zewnętrznej, zbiornik zostałby wypełniony po ok. 9. latach. Wypełnienie zbiorników końcowych po odkrywkach węglowych spowoduje zanik leja depresji (ryc. 3 i ryc. 4) i pozwoli odbudować w miarę pierwotne stosunki w systemach wodonośnych w otoczeniu jezior Powidzkiego Parku Krajobrazowego i zatrzymać wieloletni trend obniżania się poziomu wody w tych jeziorach. Analizowane warianty przerzutu wody ze szczytowego stanowiska Kanału Ślesińskiego (ryc. 5) do zbiorników końcowych po odkrywkach węglowych przedstawiono na ryc. 6 .

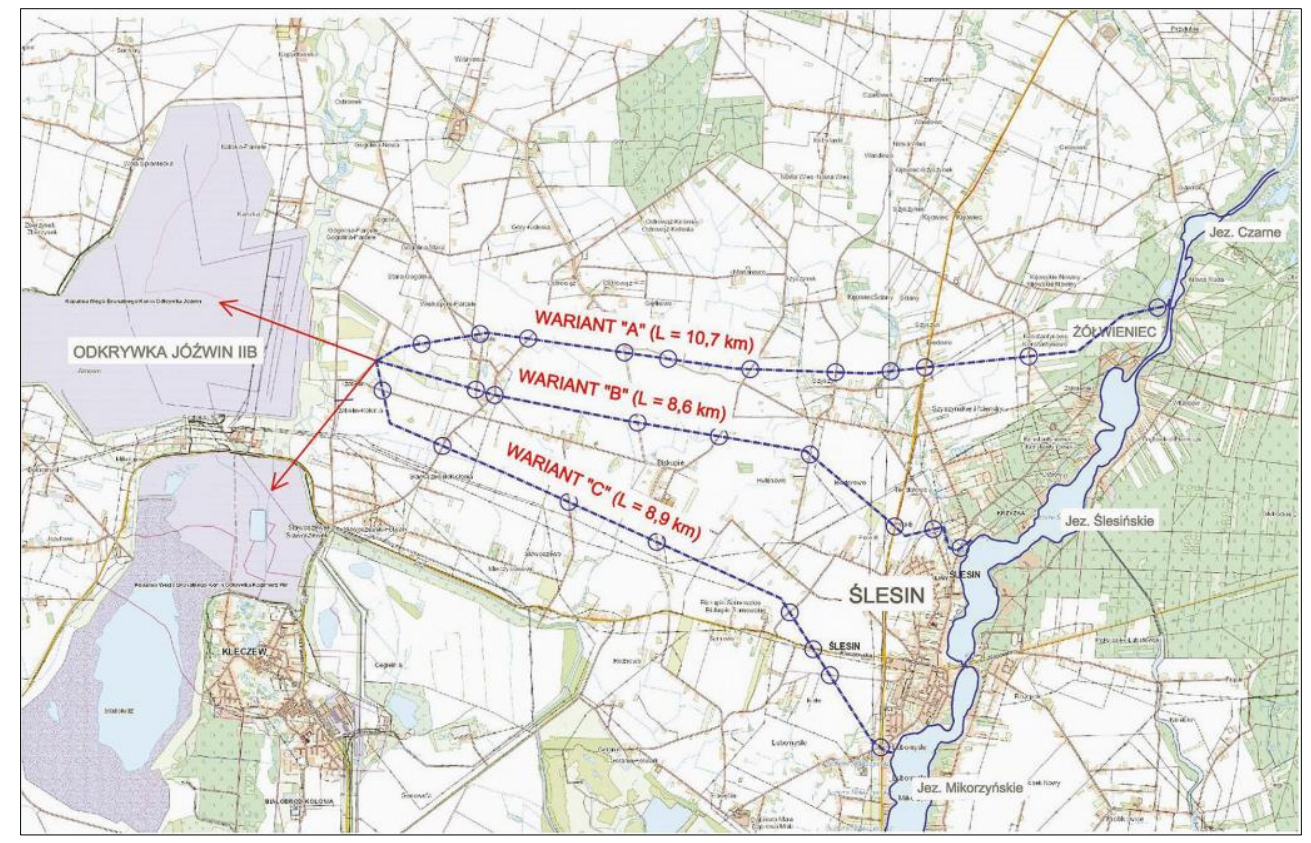

Ryc. 6. Warianty przerzutu wody z Kanału Ślesińskiego do końcowych zbiorników wodnych po odkrywkach węgla brunatnego Kazimierz Północ (Zbiornik Kleczew) i Jóźwin IIB Źródło: Przybyłek i in. 2020 
We wszystkich ukazanych na ryc. 6 wariantach trasy rurociągów przesyłowych kończą się na skraju odkrywki Jóźwin IIB, gdzie powinna zostać wykonana komora rozprężna i komora rozdzielcza, umożliwiająca rozrząd wody do zbiorników końcowych obu odkrywek (czerwone strzałki na ryc. 6). Komory te mogą być odrębne lub zintegrowane. W przypadku zbiornika Kleczew wystarczy wodę doprowadzić do Strugi Kleczewskiej, z której już obecnie woda dostarczana jest do tego zbiornika. We wszystkich wariantach przyjęto, że woda będzie pompowana ze szczytowego stanowiska Kanału Ślesińskiego przy poziomie piętrzenia 83,40 m n.p.m. (ryc. 5, poziom pomiędzy Min PP 83,17 m n.p.m. a NPP 83,67 m n.p.m.).

Poziom ten został ustalony przez wszystkie lokalne jednostki samorządowe jako optymalny dla zapewnienia właściwych warunków środowiskowych i sportowo-rekreacyjnych dla tego akwenu.

\section{Wariant ,A"}

- długość ok. 10,7 km;

- pompownia w rejonie mostu w Żółwińcu na lewym brzegu Kanału Ślesińskiego;

- rejon pompowni i trasy rurociągu słabo zagospodarowany;

- 11 większych kolizji na trasie rurociągu.

\section{Wariant „B"}

- długość ok. 8,6 km;

- pompownia w rejonie Ślesina na lewym brzegu Kanału Ślesińskiego;

- rejon pompowni średnio zagospodarowany, trasy rurociągu słabo zagospodarowany;

- 8 większych kolizji na trasie rurociągu.

\section{Wariant „C"}

- długość ok. 8,9 km;

- pompownia w rejonie Lubomyśla na lewym brzegu Kanału Ślesińskiego;

- $\quad$ rejon pompowni średnio zagospodarowany, trasy rurociągu słabo zagospodarowany;

- 8 większych kolizji na trasie rurociągu.

Uwzględniając wstępne obliczenia hydrauliczne i uwarunkowania lokalizacyjne pompowni uznano jako najwłaściwszą jej lokalizację wg wariantu „C”.

Zbiorniki wodne powstałe w wyniku rekultywacji wodnej odkrywek: Kazimierz Północ (istniejący - zalewany obecnie zbiornik Kleczew) oraz Jóźwin IIB (planowany) położone są w obszarze wododziału, rozdzielającego zlewnię Kanału Ostrowo-Gopło od zlewni Kanału Ślesińskiego (ryc. 1). Zwierciadła wody w tych zbiornikach będą podlegały wahaniom w granicach ok. $1 \mathrm{~m}$, w zależności od występujących warunków meteorologicznych. Jeżeli zbiorniki będą pełniły głównie funkcję sportowo-rekreacyjną, co jest najbardziej prawdopodobne, pożądane będzie utrzymanie w nich stabilnego poziomu wody. Do tego celu może być wykorzystana wybudowana instalacja na potrzeby szybszego wypełnienia zbiorników wodnych powstałych po odkrywkach Kazimierz Północ oraz Jóźwin IIB.

W okresach suszy można będzie przepompowywać wodę z Kanału Ślesińskiego do wcześniej wymienionych zbiorników, z wydatkiem gwarantującym utrzymanie stabilnego poziomu wody. W zasadzie jest to jedyny kierunek (sposób) wykorzystania infrastruktury wybudowanej na potrzeby szybszego wypełnienia zbiorników wodnych powstałych po odkrywkach Kazimierz Północ oraz Jóźwin IIB. 
Stan i możliwości odbudowy stosunków wodnych na Pojezierzu Gnieźnieńskim po zakończeniu...

Odwoływanie się do funkcji przeciwpowodziowej tej infrastruktury, polegającej na przerzucie nadmiaru wody z Kanału Ślesińskiego do tych zbiorników wodnych, jest nieuzasadnione ze względów ekonomicznych, ponieważ wody powodziowe można grawitacyjnie (bez kosztów) zrzucać poprzez jaz w Gawronach do Noteci w kierunku Gopła, albo poprzez śluzę Pątnów (grawitacyjnie poprzez zamknięcia motylkowe) i dalej poprzez pompownię odwrotną w Morzysławiu do Warty - bez względu na poziom wody w Warcie - przy niewspółmiernie niższych kosztach.

Po napełnieniu zbiorników końcowych, wcześniej wymienionych odkrywek, do poziomu docelowego 92,00-93,00 m n.p.m. można rozważyć ponownie koncepcję zasilania Jeziora Budzisławskiego (do poziomu 98,40 m n.p.m.) oraz Jeziora Wilczyńskiego (do poziomu 98,20 m n.p.m.) wodami pochodzącymi z wypełnionego zbiornika końcowego Jóźwin IIB. Podane poziomy wynikają z decyzji z dnia 24.06.2010 r., znak: DSR.VI.6213-90/10, wydanej przez Marszałka Województwa Wielkopolskiego w sprawie udzielenia pozwolenia wodnoprawnego na zasilanie bezpośrednie Jeziora Budzisławskiego oraz Jeziora Wilczyńskiego wodami z odwodnienia O/Jóźwin IIB.

W decyzji tej ustalono docelowe poziomy zwierciadła wody na rzędnych:

- 98,40 m n.p.m. - dla Jeziora Budzisławskiego;

- 98,20 m n.p.m. - dla Jeziora Wilczyńskiego.

$\mathrm{Z}$ technicznego punktu widzenia przerzut ten będzie podobny jak przerzut wody z Kanału Ślesińskiego do odkrywek, ponieważ:

a) odległość przesyłu wynosi ok. $8 \mathrm{~km}$;

b) geometryczna wysokość podnoszenia wynosi ok. $19 \mathrm{~m} \mathrm{(z} \mathrm{uwzględnieniem} \mathrm{morfologii}$ wododziału pomiędzy jeziorami a zbiornikiem końcowym po odkrywce Jóźwin IIB).

Wydatek do zasilania tych jezior uznaje się za wystarczający w wielkości od $0,1 \mathrm{~m}^{3} / \mathrm{s}$ do $0,15 \mathrm{~m}^{3} / \mathrm{s}$, w warunkach, które zaistnieją po likwidacji leja depresji po odkrywkach. Zagadnienie może być rozważane już po wypełnieniu zbiornika końcowego O/Jóźwin IIB, w szczególności po zbadaniu jakości wody w tym zbiorniku i jej przydatności do zasilania wcześniej wymienionych jezior, z równoczesnym zapewnieniem warunków ochrony zlewni wyżej wymienionego zbiornika przed zanieczyszczeniami. Docelowe poziomy wody w wcześniej opisywanych jeziorach oraz pozostałych jeziorach PPK, można ustalić ponownie, na podstawie wnikliwej analizy warunków: środowiskowych, gospodarczych, społecznych i formalno-prawnych.

\section{Podsumowanie i wnioski}

1) Bezpośrednie zasilanie jezior Powidzkiego Parku Krajobrazowego (PPK) wodą pobieraną z Kanału Ślesińskiego jest niemożliwe ze względów środowiskowych, związanych z ochroną tzw. jezior ramienicowych z dominacją makroglonów z gromady Charophyta w strefie litoralu.

2) Rekomendowane jest pośrednie zasilanie jezior PPK poprzez wypełnienie zbiorników końcowych po odkrywkach Kazimierz Północ oraz Jóźwin IIB wodą pompowaną z Kanału Ślesińskiego (wsparcie naturalnej odnawialności wód podziemnych w tych zbiornikach). 
3) Warunki do bezpośredniego zasilania jezior PPK mogłyby zaistnieć w przyszłości wodą czerpaną ze zbiornika końcowego odkrywki Jóźwin IIB, po zakończonej rekultywacji wodnej tego wyrobiska. W tym celu, przy urządzaniu czaszy zbiornika Jóźwin IIB, należałoby przewidzieć usypanie w jego krawędzi północno-zachodniej - od strony jezior Powidzkiego Parku Krajobrazowego - sztucznego złoża filtracyjnego i ułożenia w nim rusztu drenów poziomych dla ujęcia sztucznej infiltracji w postaci np. studni promienistych o łącznej wydajności ok. $0,1 \mathrm{~m}^{3} / \mathrm{s}\left(8,6\right.$ tys. $\left.\mathrm{m}^{3} / \mathrm{d}\right)$. Woda infiltracyjna $\mathrm{z}$ tego ujęcia byłaby kierowana do jezior lub na ich przedpole filtracyjne (piaski sandrowe) trasą zaprojektowanego już w ubiegłych latach rurociągu. Funkcja tego układu stwarzałaby szansę długoterminowej odbudowy i utrzymywania optymalnych stosunków wodnych w kompleksie jezior PPK.

4) Istotne jest przeznaczenie zbiornika końcowego odkrywki Jóźwin IIB na cele ściśle retencyjne. Ze względu na konieczność utrzymania dobrej jakości wody zbiornika, zlewnię zbiornika końcowego należy zabezpieczyć przed dopływem zanieczyszczeń i eutrofizacją wód. Powyższe zagadnienia powinny zostać uwzględnione w dokumentach planistycznych Gminy Kleczew, związanych z zagospodarowaniem przestrzennym obszaru zlewni zbiornika końcowego (retencyjnego) po odkrywce Jóźwin IIB.

5) Zasoby wodne Warty w przekroju wlotu do Kanału Ślesińskiego, w tym zasoby wody zgromadzonej w zbiorniku Jeziorsko, gwarantują możliwość alimentowania zasobów wodnych szczytowego stanowiska Kanału Ślesińskiego w takim zakresie, aby można było pompować wodę do zbiorników końcowych po odkrywkach Kazimierz Północ oraz Jóźwin IIB, z wydatkiem 1,26 m³/s przez ok. 6 miesięcy w roku, głównie w półroczu zimowym. W półroczu zimowym woda w Kanale Ślesińskim ma lepszą jakość od wody w półroczu letnim.

6) Wodę do zbiorników końcowych po odkrywkach Kazimierz Północ oraz Jóźwin IIB zaleca się pompować w półroczu zimowym, ponieważ w tym okresie na ogół nie występują niedobory wody na szczytowym stanowisku Kanału Ślesińskiego, a pogorszenie klimatu akustycznego wystąpi w okresie znikomej aktywności sportowo-turystycznej na tym terenie. Rocznie można przepompować wodę do zbiorników końcowych po odkrywkach Kazimierz Północ oraz Jóźwin IIB w ilości ok. 20 mln $\mathbf{~ m}^{3}$.

7) Wypełnianie zbiornika końcowego po odkrywce Jóźwin IIB, o pojemności ok. $213 \mathrm{mln} \mathrm{m}^{3}$, można skrócić z planowanych 33. lat do ok. 10 lat, przy założeniu, że rocznie będzie pompowane z Kanału Ślesińskiego ok. $20 \mathrm{mln} \mathrm{m}^{3}$ wody.

8) W półroczu zimowym zagwarantowana jest możliwość zaspokojenia potrzeb obecnych beneficjentów zasobów wodnych szczytowego stanowiska Kanału Ślesińskiego oraz potrzeb przerzutu wody do zasilania zbiorników końcowych odkrywki Kazimierz Północ oraz odkrywki Jóźwin IIB w ilości $\mathbf{1 , 2 6} \mathbf{~ m}^{3} / \mathbf{s}$, w ramach aktualnego pozwolenia wodnoprawnego - decyzja Wojewody Wielkopolskiego nr SR.II-6.6811-45/06 z dnia 22 grudnia 2006 r. oraz decyzja Prezesa Krajowego Zarządu Gospodarki Wodnej (KZGW) nr KZGW-oa-22a/ 425/07/MP z dnia 05 kwietnia 2007 r. udzielające RZGW w Poznaniu pozwolenia wodnoprawnego dla obiektów hydrotechnicznych Kanału Ślesińskiego z przerzutem wody z rzeki Warty na stanowisko szczytowe kanału i rzeki Noteć. 
Stan i możliwości odbudowy stosunków wodnych na Pojezierzu Gnieźnieńskim po zakończeniu...

\section{Bibliografia}

Blechacz J., Karpa Z., 1969, Odwodnienie kopalń węgla brunatnego w rejonie Konina, Przewodnik XLI Pol. Tow. Geol, Wydawnictwa Geologiczne, Warszawa: 59-63.

Dąbrowski S., 1990, Hydrogeologia i warunki ochrony wód podziemnych Wielkopolskiej Doliny Kopalnej, Wyd. SGGW-AR, Warszawa.

Fiszer J., 2013, Model numeryczny warunków hydrogeologicznych dla projektowanej odkrywki Ościsłowo, HYDROS Biuro Usług Hydrogeologicznych i Kompleksowych Analiz Środowiska, Oborniki Śląskie, Archiwum RDOŚ Poznań.

Gąbka M., Burchardt L., 2006, Ramienice zbiorników wodnych Powidzkiego Parku Krajobrazowego (Wielkopolska), Fragmentata Floristica et Geobotanica Polonica, 13(2): 387398.

Ilnicki P., 1996, Wpływ drenażu odkrywek wegla brunatnego na walory rekreacyjne Pojezierza Gnieźnieńskiego, Aura, 11: 10-12.

Ilnicki P., 2008, Ratowanie jezior Powidzkiego Parku Krajobrazowego, Biuletyn Parków Krajobrazowych Wielkopolski, 14(16): 47-65.

Ilnicki P., Orłowski W., 2006a, Ocena oddziaływania odwodnienia odkrywek w rejonie Kleczewa prowadzonych przez kopalnię wegla brunatnego Konin w Kleczewie, na poziomy wody w jeziorach położonych na wododziale rzeki Noteci $i$ Warty, Ekspertyza, rys. 44, fot. 38, Polskie Towarzystwo Rybackie, Zarząd Krajowy, Poznań: 206.

Ilnicki P., Orłowski W., 2006b, Klęska ekologiczna w Powidzkim Parku Krajobrazowym, Aura, 10: $11-14$.

Ilnicki P., Orłowski W., 2007, Problemy gospodarowania woda w otoczeniu Kopalni Wegla Brunatnego ,Konin”, Gospodarka Wodna, 9: 383-386.

Ilnicki P., Orłowski W., 2011, Rezygnacja z retencjonowania wody na wododziale Noteci $i$ Warty sprzeczna z zasada zrównoważonego rozwoju, Gospodarka Wodna, 8.

Kędziora A., 2008, Bilans wodny krajobrazu konińskich kopalni odkrywkowych w zmieniajacych się warunkach klimatycznych, R. Gleboz., Tom LXI, 2: 104-118.

Kędziora A., 2011, Warunki klimatyczne i bilans wodny Pojezierza Kujawskiego, Rocznik Gleboznawczy, Tom LXII, 2: 189-203.

Kępińska-Kasprzak M., 2015, Susze hydrologiczne w Polsce i ich wplyw na gospodarowanie woda, Bogucki Wydawnictwo Naukowe, Poznań: 1-132.

Marszalewski W., Operacz M., Pietruszewska L., Solarczyk A., 2012, Ocena możliwości odprowadzania wód z planowanej o/Ościstowo do wód powierzchniowych położonych w obszarze NATURA 2000, Opracowanie na zlecenie Kopalni Węgla Brunatnego „Konin”, Toruń, Niepubl.

Nowak B., 2018, Rola jezior w drenażu i zasilaniu wód podziemnych na Pojezierzu Gnieźnieńskim $w$ warunkach naturalnych $i$ antropopresji hydrodynamicznej, Rozprawa doktorska, Instytut Geologii UAM, Poznań: 1-178.

Nowak B. (red. nauk.), 2019, Jezioro Powidzkie wczoraj i dziś, Instytut Meteorologii i Gospodarki Wodnej, Państwowy Instytut Badawczy, Warszawa.

Nowak B., 2020, Znikające jeziora, Gazeta Obserwatora IMGW (ISSN: 0208-4325): 22-25. 
Nowak B., Przybyłek J., 2020, Recharge and drainage of lakes in the Powidzki Landscape Park in conditions of increased anthropogenic an environmental pressure (central - western Poland), Geological Quarterly, 64(1): 205-219.

PROXIMA S.A., Praca zbiorowa, 2006, Dokumentacja geologiczna złoża wegla brunatnego Ościsłowo w kategorii B, C1 i C2, Wrocław, Niepubl.

Przybyłek J., 2011, Warunki hydrogeologiczne i problemy odwadniania odkrywek węgla brunatnego we wschodniej Wielkopolsce, Rocznik Gleboznawczy, 62(2): 341-356.

Przybyłek J., Nowak B., 2011, Wpływ nizówek hydrogeologicznych i odwodnień górniczych na systemy wodonośne Pojezierza Gnieźnieńskiego, Biuletyn PIG, $\mathrm{Nr} 445$, seria Hydrogeologia, z. XII/2: 513-527.

Przybyłek J., 2018, Aktualne problemy odwadniania złóż węgla brunatnego $w$ Wielkopolsce, Górnictwo Odkrywkowe, 2/2018: 5-14.

Przybyłek J., 2020, Środowiskowe uwarunkowania skutków eksploatacji odkrywkowej węla brunatnego na Pojezierzu Gnieźnieńskim, Przegląd Geologiczny, 68(8): 645-654.

Przybyłek J., Gębka M., Kamiński W., Wiliński R., 2020, Analiza możliwości zasilania jezior Powidzkiego Parku Krajobrazowego zasobami wodnymi rzeki Warty oraz szczytowego stanowiska Kanatu Ślesińskiego, Samorząd Województwa Wielkopolskiego, Wojewódzkie Biuro Planowania Przestrzennego w Poznaniu, Bogucki Wydawnictwo Naukowe, Poznań, https://wbpp.poznan.pl/2021/07/30/analiza-mozliwosci-zasilaniajezior (dostęp: 15.08.2021).

Tarnowski R., Bołwach A., Małecki M., 2020, Monitoring środowiska wodnego rejonu odkrywek wegla brunatnego Konin S.A. w roku hydrologicznym 2019 (XI 2018 - X 2019), Tom II, Część I - Odkrywka Jóźwin i Odkrywka Kazimierz w likwidacji, Poltegorprojekt Sp. z o.o., Wrocław, Archiwum KWB Konin. 